\title{
Promotion of miR-22I-5p on the Sensitivity of Gastric Cancer Cells to Cisplatin and Its Effects on Cell Proliferation and Apoptosis by Regulating DDRI [Retraction]
}

Jiang X, Jiang M, Guo S, Cai P, Wang W, Li Y. Onco

Targets Ther. 2020;13:2333-2345.

At the authors request, the Editor and Publisher of OncoTargets and Therapy wish to retract the published article. On review of the study data the authors found that 23 of the 27 squamous cell carcinomas reported in Table 1 had been mistakenly identified as coming from gastric cancer patients. These patients were subsequently identified as esophageal cancer patients and should not have been included in the data analysis. As a result, the authors have determined the findings of the study are invalid and requested for the article to be retracted.

The authors wish to apologise for this error.

Our decision-making was informed by our policy on publishing ethics and integrity and the COPE guidelines on retraction.

The retracted article will remain online to maintain the scholarly record, but it will be digitally watermarked on each page as "Retracted".

\section{Publish your work in this journal}

OncoTargets and Therapy is an international, peer-reviewed, open access journal focusing on the pathological basis of all cancers, potential targets for therapy and treatment protocols employed to improve the management of cancer patients. The journal also focuses on the impact of management programs and new therapeutic agents and protocols on patient perspectives such as quality of life, adherence and satisfaction. The manuscript management system is completely online and includes a very quick and fair peer-review system, which is all easy to use. Visit http://www.dovepress.com/ testimonials.php to read real quotes from published authors. 